\title{
LIFE CYCLE COST EVALUATION FOR HOUSEHOLD GARBAGE DISPOSER SYSTEM
}

\author{
住宅用ディスポーザシステムの LCC 評価 \\ Kanako TOYOSADA*, Yasutoshi SHIMIZU**, Kaori KITAGUCHI*** \\ and Masayuki OTSUKA**** \\ 豊貞 佳奈子, 清 水康 利, 北口 かおり，大塚雅 之
}

\begin{abstract}
Disposer wastewater treatment systems, comprised of food waste disposers and wastewater treatment tanks, are approved and have spread quickly in Japan. Direct discharge disposers, which discharge wastewater directly into sewer, are under consideration of approval by authorities. This paper therefore compares types of disposer installation using the life cycle cost analysis method. The LCC increased in all cases of disposer installation. In cases which involved 100 households or less the LCC of introducing direct discharge disposers was lower than that of installing disposer wastewater treatment systems. When disposer wastewater treatment systems are installed, user costs increase and waste/wastewater treatment costs to the public sector decrease. Subsequently, certain measures may be required, such as returning some of the public sector cost savings to users.
\end{abstract}

\section{Keywords : Household disposer, Disposer system, Garbage treatment, Life Cycle Cost ディスポーザ、ディスポーザシステム、生ごみ処理、ライフサイクルコスト}

\section{Introduction}

In 1998, the former Japanese Ministry of Construction approved the introduction of disposer wastewater treatment systems, which integrate food waste disposers and a wastewater treatment tank, on the premise that the systems would not increase the effluent impurity load for municipal wastewater treatment infrastructure. These systems have since spread rapidly mainly in newly built multi-storey apartment complexes in major cities such as Tokyo and Osaka. On the other hand, the spread of these systems in detached houses is not progressing, due to space restrictions that prohibit installation of a wastewater treatment tank.

There are so-called direct discharge disposers, which do not have a wastewater treatment tank and which discharge wastewater directly into sewer. Direct discharge disposers are much in demand for their versatility, not only in multi-storey apartments but also in detached houses and in reconstruction projects. Hence, the introduction of direct discharge disposers is being considered by authorities on a trial basis in order to examine their influence on the water environment ${ }^{1)}$.

The authors have been conducting a series of research studies to seek a method to evaluate quantitatively the influence of disposer usage on the environment in full view of municipal environmental infrastructures. The previous reports 2)-4) looked at disposer wastewater treatment systems for multi-storey apartment complexes and examined $\mathrm{CO}_{2}$ emission $\left(\mathrm{LCCO}_{2}\right)$, the major cause of global warming, and energy consumption (LCE).

In order to promote the appropriate use of disposers it is important not only to evaluate environmental aspects but also to assess the Life Cycle Costs (LCC hereafter) covered by users and the public sector. Presently cost studies including these factors are very limited ${ }^{5}$. Disposer wastewater treatment systems centrally process disposer drainage and kitchen drainage, which are discharged from every unit in a multi-storey apartment complex, using a wastewater treatment tank installed underground within the premises of the apartment complex. Therefore, the cost per household, for construction and operation of the wastewater treatment tank, which users will pay, may vary with the housing scale (number of households per building). However, in previous research, these were treated uniformly and there are no examples in which disparities in housing scales were examined. Market prices of disposer wastewater treatment systems have become
* Osawa Memorial Institute of Architectural Environmental Engineering, Kanto Gakuin Univ. Research Institute for Material Recycles, Organization for Recycling of Organic Resources

** Guest Prof., Graduate School of Life and Environment Science, University of Tsukuba, Ph. D.

*** Research Institute for Material Recycles, Organization for Recycling of Organic Resources, Ph. D.

**** Prof., Dept. of Architecture, College of Engineering, Kanto-Gakuin Univ., Dr. Eng.
関東学院大学大沢記念建築設備工学研究所 研究員 財)有機質資源再生センター循環型社会研究所 研究員

筑波大学大学院生命環境科学研究所 客貝教授·工博

(䝧)有機質資源再生センター循環型社会研究所

研究員 . 工博 


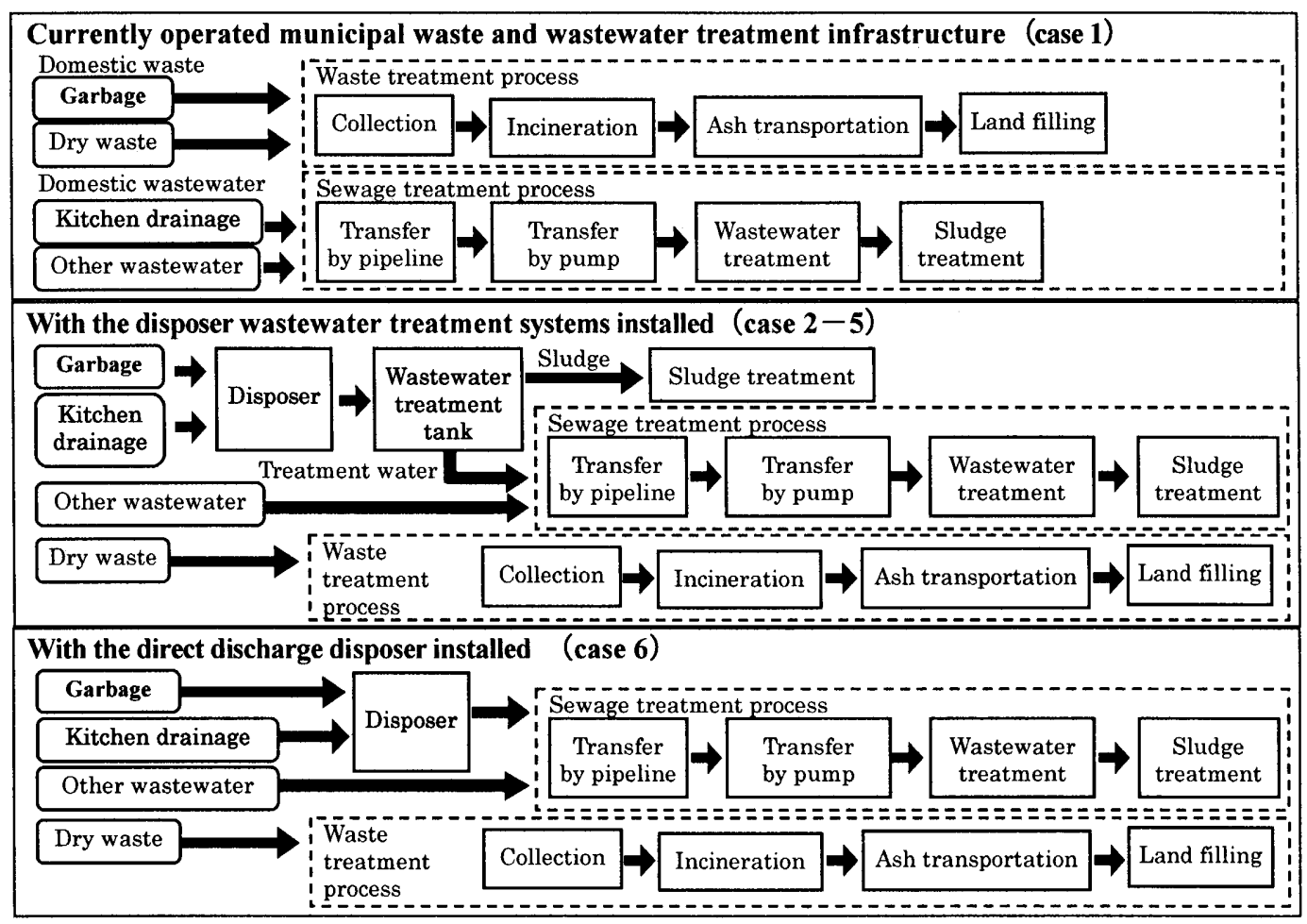

Fig.1 The Models for calculating the LCC

much more affordable due to their rapid and extensive diffusion but the previous studies did not include evaluation of the influence of market prices of disposer wastewater treatment systems on disposer usage, nor did they include detailed analysis of initial and operating costs.

This paper therefore evaluates the LCC from disposer installation through the entire processes from construction to operation, and also as evaluates the LCC according to the housing scale and with market prices of disposers taken into account.

\section{Study methodology}

\section{(1) Models for LCC calculations}

The model for calculating the LCC in this study is defined as shown in Fig. ${ }^{2}$ ). Items that were calculated are shown in Table 1. Case 1 represents the currently operated typical waste/wastewater treatment infrastructure without a disposer. Case 1 was therefore used as a reference for evaluating the influence of disposer installation. Cases 2 to 5 exemplify typical disposer wastewater treatment systems, which treat garbage and kitchen drainage and discharge wastewater from treatment processes. In these cases various housing scales and various treated water qualities (multistorey apartment complexes: BOD $0.2 \mathrm{~kg} / \mathrm{m}^{3}$ or lower, detached houses: $0.3 \mathrm{~kg} / \mathrm{m}^{3}$ or lower) were applied for the LCC calculations. More specifically, four different housing scales were used in the calculations; large (300), medium (100) and small (30) scales of multi-storey apartment complexes, plus detached houses. The number of residents per household was assumed to be $3.5^{6}$ for the LCC calculations. Case 6 classified the direct discharge disposer,
Table 1 Items to be calculated in the LCC evaluation

\begin{tabular}{|l|l|}
\hline \multicolumn{1}{|c|}{ Calculation objects } \\
\hline \hline Case 1 & $\begin{array}{l}\text { Currently operated municipal waste and wastewater } \\
\text { treatment infrastructure (without disposer) }\end{array}$ \\
\hline Case 2 & $\begin{array}{l}\text { Disposer wastewater treatment systems for multi-storey } \\
\text { apartments ( 300 houses) }\end{array}$ \\
\hline Case 3 & $\begin{array}{l}\text { Disposer wastewater treatment systems for multi-storey } \\
\text { apartments ( 100 houses) }\end{array}$ \\
\hline Case 4 & $\begin{array}{l}\text { Disposer wastewater treatment systems for multi-storey } \\
\text { apartments ( 30 houses) }\end{array}$ \\
\hline Case 5 & Disposer wastewater treatment systems for detached houses \\
\hline Case 6 & Direct discharge disposer \\
\hline
\end{tabular}

which does not employ a wastewater treatment tank.

The scope of the LCC calculations of the above-mentioned disposer wastewater treatment systems includes the disposer section, which is installed in the specified space within each residential unit, and the wastewater treatment tank section, which is installed underground (in a common use area) within the premises of each apartment complex, and a drainage pipe section, which connects the disposer and the wastewater treatment tank. The cost of these sections was evaluated during the phases of manufacturing, installation and operation. The wastewater treatment tank used for the LCC evaluation is made of FRP and the tank itself, its control panel, blower, pump, pipe layout and plumbing were all taken into account in the evaluation calculation. In addition, the cost for maintenance of the drainage pipe may increase, because the frequency of pipe cleaning increases due to installation of disposers. However, due to the lack of studies clarifying necessary cleaning frequency and associated costs, pipe 
Table 2 Design specification data of the disposer wastewater treatment systems

\begin{tabular}{|c|c|c|c|c|c|}
\hline \multicolumn{2}{|r|}{$\begin{array}{l}\text { Type(the product of } \\
\text { Company T) }\end{array}$} & \multicolumn{3}{|c|}{$\begin{array}{c}\text { NJ6200VG type } \\
\text { (for multi-storey apartments) }\end{array}$} & $\begin{array}{l}\text { NJ2D20 type } \\
\text { (for detached houses) }\end{array}$ \\
\hline \multirow{3}{*}{$\begin{array}{l}\text { 苛 } \\
0 \\
0 \\
0 \\
0 \\
0\end{array}$} & $\begin{array}{c}\text { Treatment garbage } \\
\text { weight }\end{array}$ & \multicolumn{4}{|c|}{$250 \mathrm{~g} /($ person$\cdot$ day $)$} \\
\hline & Water consumption & \multicolumn{4}{|c|}{$0.005 \mathrm{~m}^{3} /($ person $\cdot$ day $)$} \\
\hline & $\begin{array}{l}\text { Amount of electricity } \\
\text { used }\end{array}$ & \multicolumn{4}{|c|}{$0.165 \mathrm{kWh} /$ month (when using it twice per day) } \\
\hline \multirow{9}{*}{ 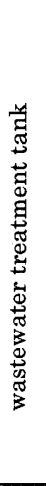 } & Housing scale & 30 households & 100 households & 300 households & 1 household \\
\hline & Number of residents & 105 persons & 350 persons & 1050 persons & 5 persons \\
\hline & $\begin{array}{c}\text { Designed amount of } \\
\text { sludge discharged }\end{array}$ & $5.51 \mathrm{~m}^{3} /$ year & $18.38 \mathrm{~m}^{3} /$ year & $55.12 \mathrm{~m}^{3} /$ year & $0.18 \mathrm{~m}^{3} /$ year \\
\hline & $\begin{array}{l}\text { Amount of electricity } \\
\text { used }\end{array}$ & $\begin{array}{c}4263.20 \\
\mathrm{kWh} / \text { year }\end{array}$ & $\begin{array}{c}10577.99 \\
\mathrm{kWh} / \text { year }\end{array}$ & $\begin{array}{c}18419.52 \\
\mathrm{kWh} / \text { year }\end{array}$ & $\begin{array}{c}420.48 \\
\mathrm{kWh} / \text { year }\end{array}$ \\
\hline & Treatment process & \multicolumn{3}{|c|}{ Aerobic digestion and contact aeration process } & $\begin{array}{l}\text { Anaerobic/aerobic digestion } \\
\text { and contact aeration process }\end{array}$ \\
\hline & Material & \multicolumn{4}{|c|}{ FRP } \\
\hline & $\begin{array}{c}\text { Designed influent } \\
\text { water quality }\end{array}$ & \multicolumn{4}{|c|}{$\begin{array}{l}\text { BOD: } 1.3 \mathrm{~kg} / \mathrm{m}^{3} \text { or lower (kitchen drainage } 0.6 \mathrm{~kg} / \mathrm{m}^{3}+\text { disposer drainage } 5.5 \mathrm{~kg} / \mathrm{m}^{3} \text { ) } \\
\text { SS }: 1.34 \mathrm{~kg} / \mathrm{m}^{3} \text { or lower (kitchen drainage } 0.4 \mathrm{~kg} / \mathrm{m}^{3}+\text { disposer drainage } 7.0 \mathrm{~kg} / \mathrm{m}^{3} \text { ) }\end{array}$} \\
\hline & $\begin{array}{l}\text { Designed effluent } \\
\text { water quality }\end{array}$ & \multicolumn{3}{|c|}{$\begin{array}{l}\text { BOD: } 0.2 \mathrm{~kg} / \mathrm{m}^{3} \text { or lower } \\
\text { SS }: 0.2 \mathrm{~kg} / \mathrm{m}^{3} \text { or lower }\end{array}$} & $\begin{array}{l}0.3 \mathrm{~kg} / \mathrm{m}^{3} \text { or lower } \\
0.3 \mathrm{~kg} / \mathrm{m}^{3} \text { or lower }\end{array}$ \\
\hline & $\begin{array}{l}\text { Designed effluent } \\
\text { volume }\end{array}$ & \multicolumn{4}{|c|}{$\begin{array}{c}0.035 \mathrm{~m}^{3} /(\text { person } \cdot \text { day })\left(\text { kitchen drainage } 0.03 \mathrm{~m}^{3} /(\text { person } \cdot \text { day })\right. \\
\left.\text { + disposer drainage } 0.005 \mathrm{~m}^{3} /(\text { person } \cdot \text { day })\right)\end{array}$} \\
\hline
\end{tabular}

cleaning was not included in these calculations. The design specification data of the disposer wastewater treatment systems used for the LCC evaluation are shown in Table 2.

It was assumed that changes in the scale of operations of facilities in the currently operated typical waste/wastewater treatment infrastructure due to disposer introduction were not made. Only operation phase costs were applied to the calculations. Maintenance costs were included in the operation phase costs.

It should be noted that the LCC evaluation in this study does not specify criteria such as the size of the municipality, but take into account from the general perspective of waste/wastewater treatment facilities, which are adopted in Japan as social infrastructures.

\section{(2) Calculation method}

The construction and operating costs of waste/wastewater treatment infrastructures were calculated, in cases in which the infrastructures treated garbage and kitchen drainage, according to each case shown in Fig. 1. The LCC was calculated for each case. With regards to the current waste/wastewater treatment infrastructure in case 1, the specific LCC based on volume at each stage of the waste/wastewater treatment process was determined subsequent to literature research. As shown in Table 3, the LCC was classified into "public sector costs" and "user costs". The details of the LCC calculations at each stage of the waste/wastewater treatment process are as follows.

\section{(1) Public sector costs}

\section{a) Waste treatment process}

Waste treatment costs covered by the public sector include expenses for the collection and incineration of waste, plus the transport and land-filling of incineration ash. According to a calculation method based on a report of the Japanese Ministry of Environment in $2002^{7}$, the treatment and maintenance cost (i.e. personnel cost, collection/transport cost, intermediate treatment
Table 3 LCC classification

\begin{tabular}{|c|c|}
\hline \multirow[b]{2}{*}{ Public sector costs } & $\begin{array}{l}\text { Wastewater treatment process cost } \\
\text { (during operation phases) }\end{array}$ \\
\hline & $\begin{array}{l}\text { Waste treatment process cost } \\
\text { (during operation phases) } \\
\text { Sludge treatment cost (with the disposer wastewater } \\
\text { treatment systems) }\end{array}$ \\
\hline \multirow[t]{3}{*}{ User costs } & $\begin{array}{l}\text { Disposer installation and operation cost } \\
\text { Wastewater treatment tank installation and operation } \\
\text { cost (with the disposer wastewater treatment systems) } \\
\text { Sludge separation and transportation cost (with the } \\
\text { disposer wastewater treatment systems) }\end{array}$ \\
\hline & Electric charge, Water and sewage charge \\
\hline & Waste management fee \\
\hline
\end{tabular}

cost, final treatment cost, vehicle purchase cost, commission cost etc.) was divided by the total volume of non-industrial waste and thus the cost incurred in the operation phase was calculated. In addition, correlation was not found when the above-mentioned waste treatment costs were analyzed for each city population size. However, since numerical dispersion was large, a confidence interval of $95 \%$ was sought, and sensitivity analysis according to an upper limit and lower limit was conducted.

Some of the waste treatment costs are financed through waste management fees (taxes), which are paid by users. Therefore, in this calculation, the amount of money that remained after deducting waste management fees from the above-mentioned waste treatment costs was classified as public sector costs. The calculation method of waste management fees will be discussed later.

Sludge discharged by disposer systems should be treated as nonindustrial waste, according to the Japanese Ministry of Environment ${ }^{8)}$, and therefore, all costs incurred by sludge treatment and disposal were classified as public sector costs when a disposer is installed. It was also assumed that those in charge of wastewater treatment tank management would provide separation of sludge in wastewater treatment and transport of sludge to the disposal site; and that costs 
incurred by these operations would be paid by users as part of the maintenance cost. Thus, these costs were classified as user costs. Consequently, the specific values for the current infrastructure were determined as calculated as above, which are shown in Table 4 .

\section{b) Sewage treatment process}

It was reported that since a correlation exists between the BOD quantities after treatment and the aeration power of a treatment tank, the BOD quantity after treatment is proportional to the soluble tank capacity of the disposer wastewater treatment system $^{9}$. Therefore, this calculation was performed from the standpoint of the sewage treatment process instead of disposer drainage, and it was assumed that the sewage treatment process costs were proportional to the BOD load. Based on sewage statistics from $2002^{10)}$, the maintenance cost (i.e. personnel, pipe line cleaning, pipe line inspections, repairs, electricity, chemicals, fuel and others) of pipe lines, pump stations and disposal sites in both public and river-basin sewage systems were divided by the total volume of treated sewage water so as to calculate the operation cost per annum. This maintenance cost per influent volume was divided by the planned sewer influent concentration BOD $0.2 \mathrm{~kg} / \mathrm{m}^{3}$, and the result is considered to be the specific value for the BOD loading per unit. When this maintenance cost per influent volume was analyzed for each city population size, as shown in Table 5, variations due to population size were large. Then, a $95 \%$ confidence interval of the cost for each population size was sought, and sensitivity analysis using the upper limit in the maximum population and lower limit in the minimum population was conducted.

Some of the wastewater treatment costs are financed through sewage charges(taxes), which are paid by users. Therefore, in this calculation, the amount of money which remained after deducting the sewage charges from the above-mentioned wastewater treatment costs was classified as public sector costs

Consequently, the specific values for the current infrastructure were determined as calculated above, and are shown in Table 4.

\section{(2) User costs}

\section{a) Waste management fee}

As of 2002 , the local authorities had charged $73.2 \%$ of domestic treatment services that excepted the bulky waste, either partly or entirely ${ }^{7}$. According to results of a survey of local authorities concerning fee-based domestic waste treatment, waste management fees vary on a weight basis within a range of 1 to 31 yen $/ \mathrm{kg}$, and $54 \%$ of the local authorities have set fees within a range of 3 to 8 yen $/ \mathrm{kg}^{11)}$. According to this investigation, it was reported that there was no correlation between the charge rate and the size of local authority ${ }^{11}$. Supposing that the average rate of 5 yen $/ \mathrm{kg}$ for waste treatment is appropriate, this figure was used in the LCC calculations as the specific cost for waste treatment on user side. Table 6 lists the cost data used in the LCC evaluation of
Table 4 Specific values for the current infrastructure (for the public sector costs)

\begin{tabular}{|c|c|}
\hline Item & $\begin{array}{c}\text { Specific values } \\
\text { (95\% confidence interval) }\end{array}$ \\
\hline $\begin{array}{l}\text { Waste treatment process cost } \\
\text { (during the operation phase) }\end{array}$ & $\begin{array}{c}31,581 \text { yen/t } \\
(28,408 \sim 31,852)\end{array}$ \\
\hline $\begin{array}{l}\text { Sludge treatment cost (with the disposer } \\
\text { wastewater treatment systems) }\end{array}$ & $\begin{array}{c}28,977 \text { yen/t }{ }^{\Uparrow} \\
(27,249 \sim 30,422)\end{array}$ \\
\hline $\begin{array}{l}\text { Wastewater treatment process cost } \\
\text { (during the operation phase) }\end{array}$ & $\begin{array}{l}\left.53 \text { yen } / \mathrm{m}^{3} 10\right) \\
(38 \sim 349)^{*}\end{array}$ \\
\hline
\end{tabular}

※The lower and upper limit of the analyzed cost according to size of population(Table 5)

Table 5 Wastewater treatment process cost according to size of population

\begin{tabular}{|c|c|c|}
\hline \multirow{2}{*}{ Size of population } & \multicolumn{2}{|c|}{$\begin{array}{c}\text { Wastewater treatment process cost } \\
\text { (during operation phases) }\end{array}$} \\
\cline { 2 - 3 } & Average & $\begin{array}{c}95 \% \text { confidence } \\
\text { interval }\end{array}$ \\
\hline \hline Less than 30,000 people & 312 & $274 \sim 349$ \\
\hline $\begin{array}{c}30,000 \text { or more people } \\
\text { less than 100,000 }\end{array}$ & 155 & $118 \sim 193$ \\
\hline $\begin{array}{c}100,000 \text { or more people } \\
\text { less than 500,000 }\end{array}$ & 92 & $126 \sim 193$ \\
\hline $\begin{array}{c}500,000 \text { or more people } \\
\text { less than 1 million }\end{array}$ & 67 & $43 \sim 91$ \\
\hline 1 million or more people & 47 & $38 \sim 56$ \\
\hline
\end{tabular}

Table 6 Cost data used for the LCC evaluation calculation of the user costs

\begin{tabular}{|l|c|c|}
\hline \multicolumn{1}{|c|}{ Item } & Unit value & Source \\
\hline \hline Electric charge & $22 \mathrm{yen} / \mathrm{kWh}$ & $\begin{array}{c}\text { Home Electric Appliance Fair } \\
\text { Trade Council }\end{array}$ \\
\hline Water charge & $151 \mathrm{yen} / \mathrm{m}^{3}$ & Tokyo Water Works $\left(20 \mathrm{~A} / 30 \mathrm{~m}^{3}\right)$ \\
\hline sewage charge & $114 \mathrm{yen} / \mathrm{m}^{3}$ & Tokyo Water Works $\left(20 \mathrm{~A} / 30 \mathrm{~m}^{3}\right)$ \\
\hline Waste management fee & $5 \mathrm{yen} / \mathrm{kg}$ & References 11 \\
\hline
\end{tabular}

user costs.

In addition, in this study, even if the waste and wastewater treatment flow changed due to disposer introduction, calculations were made assuming that waste management fees would not change.

\section{b) Disposer system}

The costs of installation and operation of a disposer system are classified as user costs. It should be noted, as explained previously, that the separation and transport of sludge is paid by the user whereas the disposal of sludge is paid by the public sector.

The costs of manufacturing, transport and installation of a disposer system were calculated based on the actual figures recorded by company $T$. The costs were then divided by the duration period of the disposer section and by the duration period of the wastewater treatment tank separately so as to calculate the cost incurred during the construction phase on an annual basis. Each duration period ${ }^{3)}$ was shown in Table 7 . The construction of the treatment tank was assumed to involve pouring of concrete. The manufacturing and installation costs of the drainage pipe, which is added with the installation of disposer wastewater 
treatment systems, were included in the installation cost of the wastewater treatment tank.

The water and sewage costs and the electricity expense of the disposer, plus the maintenance cost and the power expense for the wastewater treatment tank were totalised to acquire the operating cost. The cost of monthly maintenance checks of the treatment tank, the cost of the annual water quality analysis, and the costs of separation and transport of sludge were totalised to obtain the maintenance cost.

\section{Results and Discussion}

\section{(1) LCC of disposer wastewater treatment systems}

In order to clarify the dominant factor in the LCC of disposer wastewater treatment systems, evaluation limited to the manufactured components of disposer wastewater treatment systems was carried out. The LCC evaluation results of the installation and operation of disposer wastewater treatment systems are shown in Table 8 . It was found that the installation costs of the disposer and wastewater treatment tanks claim a large portion of the LCC. The results are sorted according to the housing scale. For the LCC of wastewater treatment tank, the relationship between the installation cost and the housing scale as well as between the operation and management costs and the housing scale was existed. In other words, the LCC per household decreases as the housing scale increases. It is also apparent that within the maintenance cost, the maintenance check cost and the water quality analysis cost particularly reduce LCC due to housing scale increases. This is because both costs consist largely of personnel expenses, the amounts of which remain unchanged, irrespective of the size of the wastewater treatment tank. Moreover, sludge separation and transportation costs shown in Table 8 are the same irrespective of the housing scale. This is because the amount of sludge discharged per house, and the sludge separation and transportation cost per $\mathrm{m}^{3}$, are the same irrespective of the housing
Table 7 Duration Period for every part of the disposer wastewater treatment systems

\begin{tabular}{|c|c|c|}
\hline \multicolumn{2}{|r|}{ Part } & Duration Period (year) \\
\hline \multicolumn{2}{|c|}{ Disposer } & 7 \\
\hline \multirow{4}{*}{ 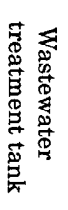 } & $\begin{array}{l}\text { Body of the Wastewater } \\
\text { treatment tank }\end{array}$ & 30 \\
\hline & Blower & 12 \\
\hline & Pump & 5 \\
\hline & Control Panel & 20 \\
\hline
\end{tabular}

Table 8 LCC of disposer wastewater treatment systems

\begin{tabular}{|c|c|c|c|c|c|c|}
\hline & \multirow{2}{*}{ Item } & \multirow{2}{*}{ Disposer } & \multicolumn{4}{|c|}{$\begin{array}{c}\text { Wastewater treatment equipment } \\
\text { (according to the housing scale) }\end{array}$} \\
\hline & & & $\begin{array}{c}300 \\
\text { houses }\end{array}$ & $\begin{array}{c}100 \\
\text { houses } \\
\end{array}$ & $\begin{array}{c}30 \\
\text { houses }\end{array}$ & $\begin{array}{l}\text { detache } \\
\text { d house }\end{array}$ \\
\hline & Installation cost & 11,429 & 2,884 & 4,543 & 11,474 & 16,781 \\
\hline \multirow{6}{*}{ 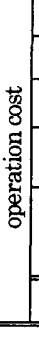 } & Electricity used & 44 & 775 & 1,371 & 2,837 & 9,251 \\
\hline & Water used & 1,693 & - & - & - & - \\
\hline & Maintenance & - & 1,000 & 3,000 & 10,000 & 24,000 \\
\hline & $\begin{array}{l}\text { Water quality } \\
\text { analysis }\end{array}$ & - & 57 & 170 & 567. & 12,000 \\
\hline & $\begin{array}{c}\text { Sludge } \\
\text { separation and } \\
\text { transportation }\end{array}$ & - & 1,841 & 1,841 & 1,841 & 1,841 \\
\hline & Subtotal & 1,736 & 3,673 & 6,382 & 15,244 & 47,092 \\
\hline & Total & 13,165 & 6,556 & 10,925 & 26,719 & 63,872 \\
\hline
\end{tabular}

scale.

A previous user survey reported that the amount of willing to pay for a disposer system was 26,956 yen/household/year ${ }^{10}$ ). This amount can be met when a disposer system is applied to a housing scale of 100 households or larger but a system installed to a housing scale of 30 households or to a detached house will cause excessive financial burden on users.

\section{(2) LCC of entire waste/wastewater treatment infrastructure}

Shown in Fig. 2 are the LCC evaluation results for the entire waste/wastewater treatment infrastructure. Compared to the current infrastructure (case 1), the LCC increases in all the other

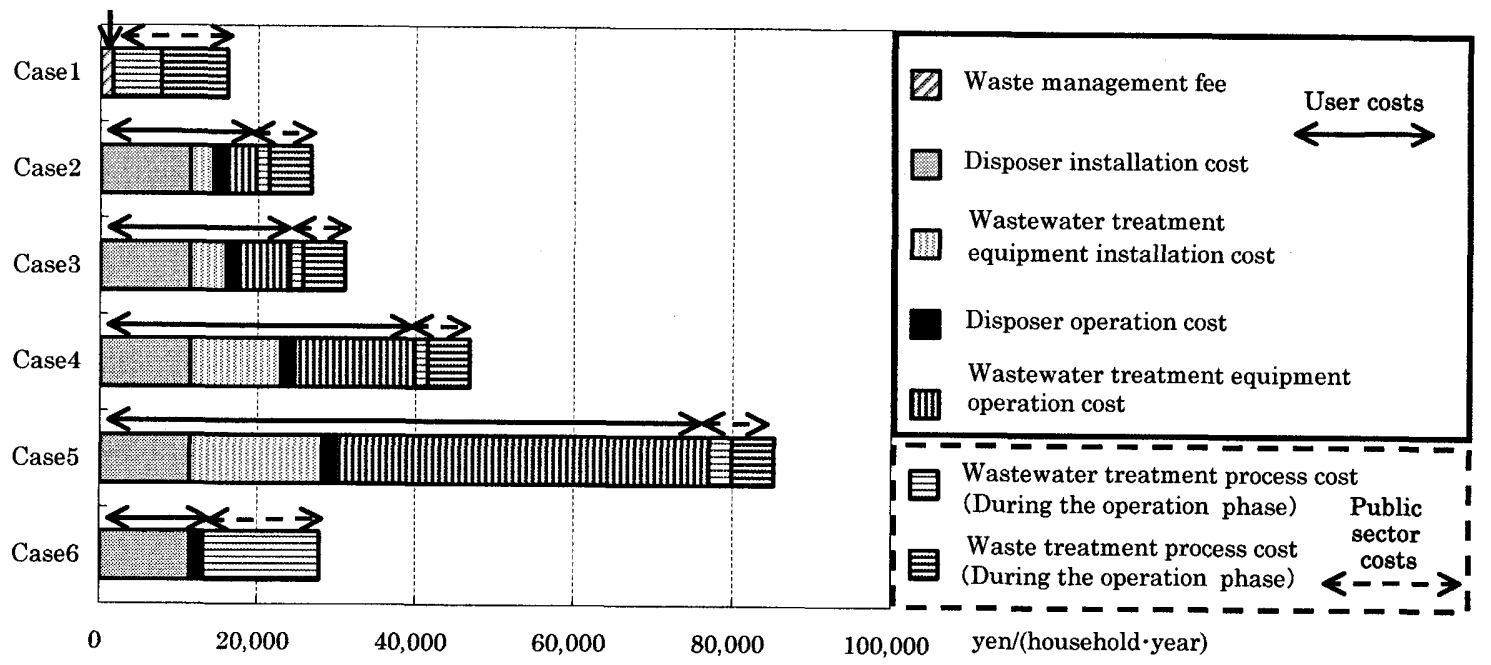

Fig.2 LCC of entire waste/wastewater treatment infrastructure 
cases upon disposer installation. The LCC of a housing scale of 300 households (case 2) upon the installation of a disposer wastewater treatment system and the LCC upon the adoption of the direct discharge disposer (case 6) are more or less the same. With scales of less than 100 households and detached houses, installation of the direct discharge disposer appears to minimize the LCC better than the application of disposer wastewater treatment systems.

According to the classification of costs, in cases 2 to 5 , where disposer wastewater treatment systems are employed, user costs increase by 12 to 48 times compared to the user costs in case 1 . In contrast, public sector costs are only 40 to $60 \%$ of the costs in case 1 , resulting in users bearing waste/wastewater treatment costs that are covered by the public sector in case 1 . In case 6 , where a direct discharge disposer is adopted, the user cost decreases but the public sector cost is more or less the same. To promote the spread of disposers, certain measures may be required, such as returning some of the waste/wastewater treatment cost savings in the public sector to users.

As shown in Table 4 the difference between the waste treatment process cost and the wastewater treatment process cost, per unit of weight, is large; waste treatment being approximately 280 times the cost of wastewater treatment. Since, the amount of domestic wastewater discharge: $200 \mathrm{~L} /$ (person-day) is about 270 times the amount of domestic waste discharge: $0.743 \mathrm{~kg} /$ (person $\cdot$ day) (Ministry of Environment data ${ }^{13)}$ ), it is considered that the treatment cost per unit of time is comparable. Moreover, in this calculation, it is assumed that the waste treatment process cost is proportional to the amount of domestic waste discharge, and the wastewater treatment process cost is proportional to the BOD load. However, it is possible that the actual cost may not be proportional to the treatment volume. Future research would be necessary to investigate actual expense.

In the case of installing direct discharge disposers, expansion of sewage treatment facilities and sludge treatment facilities may be needed due to an increase in influent load. However, in this calculation, it was assumed that facilities do not need to be expanded, due to a report that many sewage treatment facilities in Japan can retain input load within the designed range with direct discharge disposers installed and that it is highly feasible that sewage treatment facilities can secure the designed treatment water quality ${ }^{14)}$

\section{(3) LCC increases and decreases due to disposer installation}

Increases and decreases to the LCC when a disposer is installed, when costs of the wastewater treatment process, the waste treatment process, and the sludge treatment process are set to the upper and lower limits shown in Table 4, are shown compared to the current infrastructure (case 1). The LCC evaluation results in the case of disposer wastewater treatment systems installed in a representative housing scale of a 100 households multi-storey apartment complex are shown in Fig. 3, and the LCC evaluation results in the case of installation of direct discharge disposers are shown in Fig. 4.

Since the wastewater treatment process cost will change significantly with the adoption of specific values in the case of

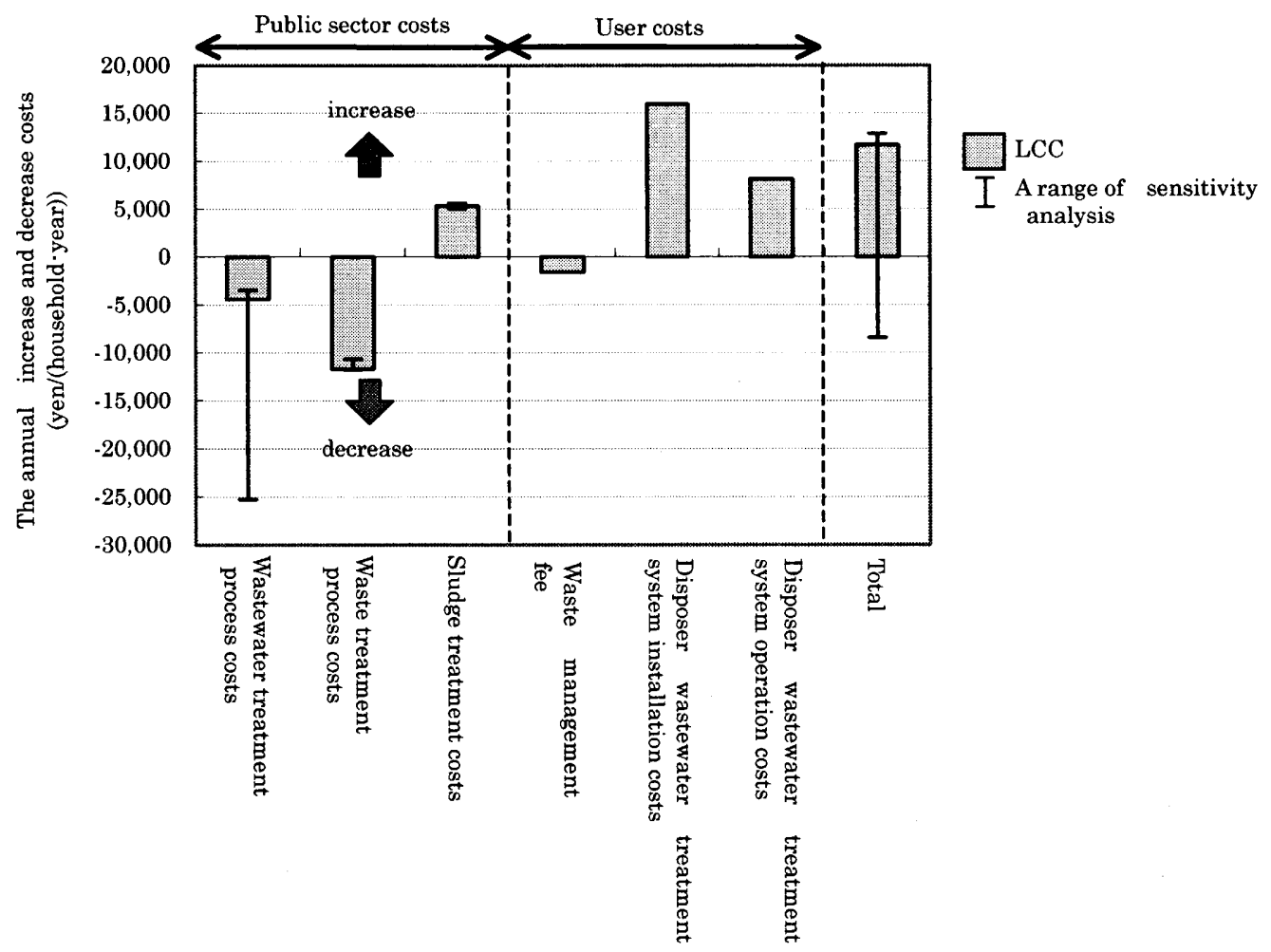

Fig.3 LCC increases and decreases due to disposer wastewater treatment systems installation (100 households) 


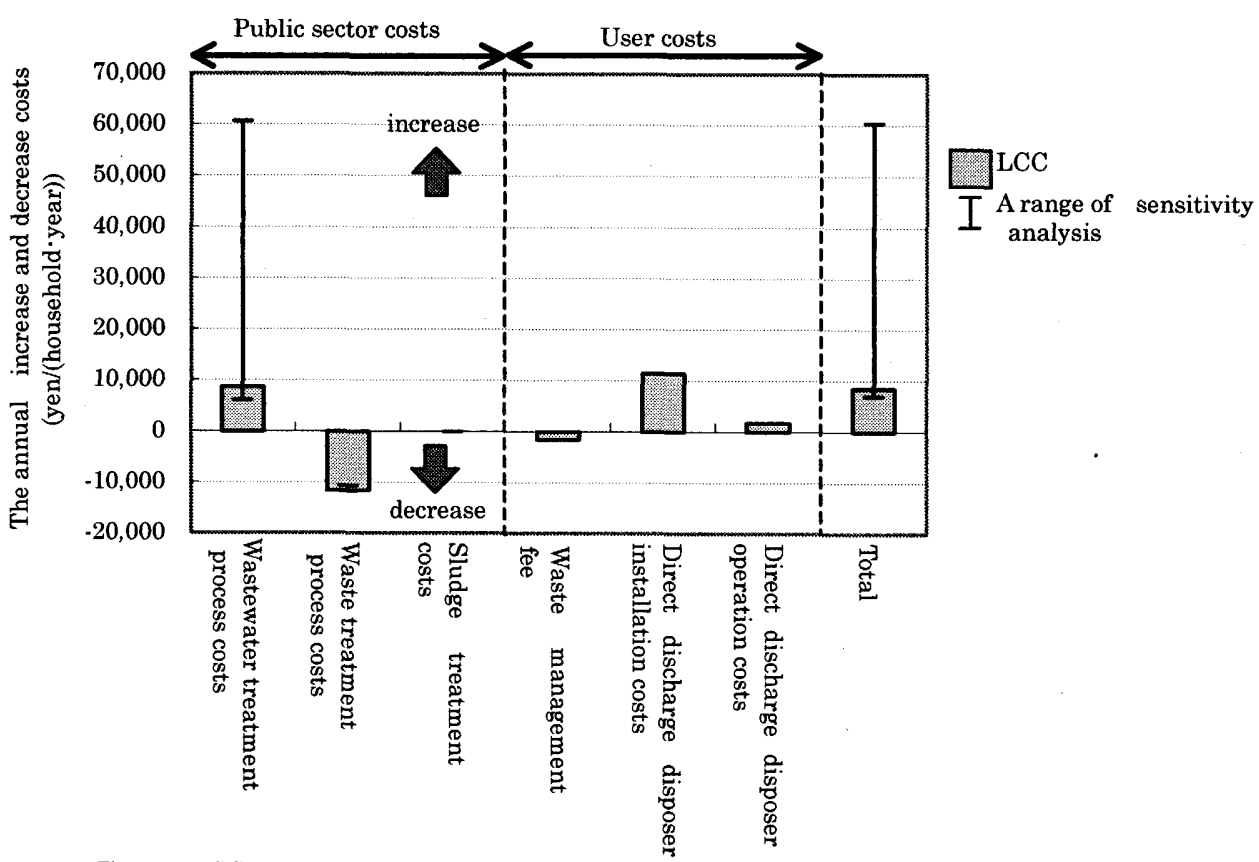

Fig. 4 LCC increases and decreases due to direct discharge disposers installation

installation of a disposer wastewater treatment system, it is clear that the calculation results in comparison with the current infrastructure (case 1) vary greatly from an increase in LCC to a decrease in LCC. Similarly, when direct discharge disposers are installed, the increase in cost varies greatly according to the wastewater treatment cost. As mentioned above, the wastewater treatment process cost varies greatly according to population size, and the cost of a small-scale facility is about 6 times the average cost. The sensitivity analysis results show clearly the LCC evaluation result varies greatly according to this difference in population size. Therefore, regional characteristics should be taken into account when conducting LCC evaluations of direct discharge disposer installation.

\section{Conclusion}

The following knowledge has been acquired as a result of the LCC evaluation on disposer systems according to housing scales ranging from 30 households to 300 households, plus detached houses, and on direct discharge disposers.

(1) Compared to the current infrastructure, the LCC increases in all cases upon disposer installation.

(2) In the case of a housing scale of 300 households the LCC upon the installation of a disposer wastewater treatment system and the LCC upon the adoption of the direct discharge disposer are more or less the same. With housing scales of less than 100 households and detached houses, the installation of the direct discharge disposer appears to minimize LCC better than the installation of disposer wastewater treatment systems.

(3) With housing scales of $\mathbf{3 0}$ households or smaller, the user costs upon the installation of a disposer system exceed the cost that users are willing to pay.
(4) The introduction of a disposer system would cause users to incur waste/wastewater treatment costs that are currently borne by the public sector. Subsequently, to promote the spread of disposers, certain measures may be required, such as returning some of the public sector cost savings to users.

(5) The wastewater treatment process cost varies greatly according to population size. The sensitivity-analysis results showed clearly the LCC evaluation results vary greatly according to these differences in population size.

In this study the LCC evaluation was carried out from the general perspective of waste/wastewater treatment facilities, which are employed in Japan as social infrastructures. In reality regional characteristics should be taken into account when conducting the LCC evaluation prior to the actual disposer installation.

\section{Acknowledgement}

The research study was conducted as part of the "Strategic Development Studies of Symbiosis Technologies with the Aim of Urban Construction Stock Reproduction", the academic frontiers promotion program 2004 by the Ministry of Education, Culture, Sports, Science and Technology.

\section{References}

1）国土交通省・国土技術政策総合研究所：ディスポーザー導入による影響評価 に関する研究報告ーディスポーザ導入時の影響判定の考え方一，国土技術政 策総合研究所資料, No.222, 2005.7

2) Kanako Toyosada, Yasutoshi Shimizu, Masayuki Otsuka:Evaluation of Environmental Impact on Disposer System for Multistory Apartments Part 1 Determination of $\mathrm{CO}_{2}$ emission and energy consumption units for $\mathrm{LCCO}_{2}$ and LCE analysieses, Journal of Enviromental engineering. Architectural Institute of Japan, No.574, pp.43-50, 2003.12 
3) Kanako Toyosada, Yasutoshi Shimizu, Masayuki Otsuka:Evaluation of Environmental Impact on Disposer System for Multistory Apartments Part 2 Analysis of $\mathrm{CO}_{2}$ Emission Change by the Introduction of Disposers, Journal of Enviromental engineering, Architectural Institute of Japan, No.585, pp.47-53, 2004.11

4) Kanako Toyosada, Kaori Kitaguchi, Yasutoshi Shimizu, Masayuki Otsuka: Evaluation of Environmental Impact on Disposer System for Multistory Apartments Part 3 Analysis of Energy Consumption Change by the Introduction of Disposers, Journal of Enviromental engineering. Architectural Institute of Japan, No.592, pp.35-42, 2005.6

5) Toru Matsumoto. Kazunori Sameshima, Hiderumi Imura: Evaluation of Disposal and Recycling System for Kitchen Garbage, Using Disposer System, Environmental Systems Research, Vol.28, pp.9-19, 2000.10

6) 社団法人日本下水道協会：下水道のためのディスポーザ排水処理システム 性能基隻（案），2001.3

7）環境省：一般廃立物処理実態調查結果，環境省ホームページ http://www.env.go.jp/recycle/waste_tech/ippan/index.html

8) 財団法人茨城県薬郕師会公賉衛生検查センターホームページ http://www. ibaraki-kensa.or.jp/disp/

9) Yoshinori Takezaki, Katushi Uryu, Takamasa Tuji, Yasutoshi Shimizu Toshihiro Sankai : Study on the Biological Treatment System with Biomass Carriers for Purifying Wastewater from Domestic Disposer System at High BOD Loading Rate, Japanese Journal of Water Treatment Biology, Vol.38, No.2, pp.103-110, 2002

10) 社団法人日本下水道協会: 平成 14 年度版下水道統計要筧, 第 59 号の 3

11）庄司元: ごみ処理の有料化に関するアンケート調查結果について, 都市清掃, 第 57 巻, 第 257 号. pp3-7, 2004.1

12) Kanako Toyosada, Kaori Kitaguchi, Yasutoshi Shimizu, Kuniharu Kojima, Toshihiko Kawamura, Kyosuke Sakaue: The Influence of Disposer experience on the User Acceptance and Environmental Awareness, Journal of RIEMAM , No.57, 2005.12

13) 環境省 : 平成 17 年版循環型社会白書, 2005

14) Yasutoshi Shimizu, Kaori Kitaguchi, Kanako Toyosada, Yoshinori Takezaki, Toshihiro Sankai, Yuhei Inamori : Evaluation of Water Environmental Impact on Household Garbage Disposers. Summaries of Technical Papers of Annual Meeting Architectural Institute of Japan, Environmental Engineering I, pp.531-532, 2004.8

\section{和文要約}

\section{1.はじめに}

ディスポーザシステムは大都市圈の集合住宅を中心として急速に普 及が進んでいるが, 最近では排水処理槽を設置しない直接放流式ディ スポーザについても導入時の水環境への影響評価が進められている。

本研究では，システム及び直接放流式ディスポーザ導入時のライフ サイクルコスト（以下，LCC）について評価を行い，住宅規模別に考 察した。

\section{2. 試算方法}

本研究の LCC 試算モデルを図 1 のごとく定義し，各モデルで生ご みと台所排水を処理した場合の LCC 評価を行った。ケース 1 は生ご みと台所排水を現状の廃棄物・排水処理インフラで処理するモデル, ケース 2〜5 は各住宅規模のディスポーザシステムで所定の処理水質 まで浄化後下水道へ放流するモデルとした。試算対象とした住宅規模 は，集合住宅について大規模型 (300 戸), 中規模型 (100 戸), 小規 模型（30 戸）の 3 種類と，戸建住宅とした。ケース 6 は排水処理槽を 設置せず，ディスポーザ排水を直接下水道へ放流するモデルとした。 廃棄物・排水処理インフラについては，都市規模等一定の条件を設定
せず，社会資本として日本で採用されている施設全体を平均化した評 価を行うものとした。また, ディスポーザ導入による施設の規模変更 は行わないものと仮定し, 運用段階のみを試算対象とした。インフラ 部の LCC 原単位は文献調査等により設定し, 上限・下限值による感 度分析を合わせて実施した。

\section{3. 結果と考察}

(1) ディスポーザシステムの LCC 評価結果

ディスポーザシステムの製品部分に限定した LCC は，設置費・維 持管理費とも排水処理槽部にスケールメリットが認められ，住宅規模 が大きいほど戸あたり単価が小さくなっている。特に保守点検費・水 質分析費のスケールメリットが大きいことが分かった(表 8)。

既報のディスポーザの利便性に対する支払意思額平均值は 26,956

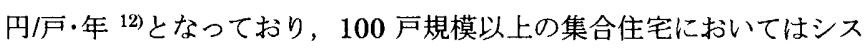
テム導入時のユーザー負担費用が許容範囲内と考えられるが, 30 戸規 模・戸建住宅においてはユーザ一負担が過大となることが分かった。

\section{(2) 廃棄物·排水処理インフラ全体の LCC 評価結果}

廃棄物・排水処理インフラ全体の LCC 評価では, ディスポーザ導 入の設定全ケースにおいて現状より LCC が増加する結果となった。 100 戸規模システム導入時と直接放流式ディスポーザ導入時の LCC が同程度となり，100 戸規模以下の住宅では，システムよりも直接放 流式ディスポーザの導入が有利と考えられる（図 2)。負担区分別に見 ると, システム導入時のユーザー負担費用が現状の 12〜 48 倍に対し, 公共負担費用は $0.4 \sim 0.6$ 倍と, 現状で公共負担となっている廃棄物・ 排水処理費用をユーザーが負担する結果となった。公共負担費用削減 分を一部ユーザーに還元するなどの措㯰が必要であると考えられる。

\section{(3) 廃棄物·排水処理インフラ全体の LCC 感度分析結果}

廃棄物・排水処理インフラの原単位上限值・下限值による LCC 感 度分析評価では, ディスポーザシステム導入時は, 採用原単位により 下水処理費が大きく変化するため, 試算結果が現状と比較して增加側 （+）から削隇側（一）に大きく変化することが明らかとなった（図 3)。直接放流式ディスポーザ導入時も同様に，下水処理費によって増 加值が大きく変化している（図 4)。下水処理費は都市規模による差異 が大きく，小規模施設では平均の約 6 倍となっており，感度分析結果 がこれに引っ張られる結果となった。よって，ディスポーザ導入検討 時は，地域特性を考慮した評価が重要となる。

\section{4. 結論}

ディスポーザ導入時の LCC 評価を行った結果，設定全ケースにお いて導入時の LCC が增加した。システム導入時は住宅規模によるス ケールメリットが確認され，300 戸規模の集合住宅ではシステムと直 接放流式ディスポーザの LCC が同程度となり，100 戸規模以下ではシ ステムよりも直接放流式ディスポーザの導入が有利と考えられた。シ ステム導入時には，現状で公共負担となっている廃棄物・排水処理費 用をユーザーが負担することとなり，30 戸規模以下ではシステム導入 時のユーザー負担費用がディスポーザの利便性に対する支払意思額を 超えることが分かった。公共負担費用削隇分を一部ユーザーに還元す るなどの措置が必要であると考えられる。また，下水処理費用が都市 規模により大きく変化し，これが評価結果に大きく影響するため，デ イスポーザ導入検討においては地域特性を考慮した評価が重要となる。

(2006年 5 月 10 日原稿受理， 2006 年10月11日採用決定) 